\title{
Regional aspects of humanitarization of university education
}

\section{Aspectos regionais da humanitarização da educação universitária}

\section{Aspectos regionales de la humanitarización de la educación universitaria}

\author{
Marina Georgiyevna Sergeeva ${ }^{1}$ iD, Irina Vyacheslavovna Vlasyuk ${ }^{2}$ iD, \\ Nikolai Mikhailovich Borytko² ${ }^{\text {iD }}$, Marina Nikolaevna Podolskaya2 iD, \\ Lyudmila Nikolaevna Kanishcheva² iD
}

\footnotetext{
${ }^{1}$ Research Institute of the Federal Penitentiary Service of Russia, Moscow, Russian.

${ }^{2}$ Volgograd State University, Volgograd, Russian.
}

\section{Corresponding author:}

Marina Georgiyevna Sergeeva

Email: sergeeva198262@mail.ru

\begin{abstract}
How to cite: Sergeeva, M. G., Vlasyuk, I. V., Borytko, N. M., Podolskaya, M. N., \& Kanishcheva, L. N. (2021). Regional aspects of humanitarization of university education. Revista Tempos e Espaços em Educação, 14(33), e15254. http://dx.doi.org/10.20952/revtee.v14i33.15254
\end{abstract}

\begin{abstract}
Modern university education in Russia requires multidimensional changes. One of the main directions is the optimization of the educational environment, in particular the management system. First of all, changes should take place at the level of education managers, who combine the qualities of a teacher, manager and psychologist. This necessity explains the increased requirements for the educational management. On the one hand, an important aspect is the competence of educational managers, on the other hand, we should deal with the system of interaction between managers and other participants of the university educational environment. Only a harmonious combination of these factors allows the university to function at the proper level. The problem of communication management in educational institutions is one of the most significant in the field of higher education. Communication is seen as one of the main resources for the development and growth of any organization. Communication as the process of sharing knowledge and information significantly affects the efficiency of an organization. The challenge of communication management is primarily in the fact that there are no clear criteria for monitoring the communication environment. This fact actualizes the problems of empirical research of communication management in the university education system. The most important dimension of optimization is the improvement of the communication environment, associated with the competence of employees and the system of their interaction. Thus, optimization of the communication environment makes it possible not only to improve management and communication processes, but also has a beneficial effect on the functioning of the university as a whole.
\end{abstract}


Keywords: Communication. The effectiveness of communications. Educational management. Communication management. The effectiveness of higher education.

\section{RESUMO}

A educação universitária moderna na Rússia requer mudanças multidimensionais. Uma das principais direções é a otimização do ambiente educacional, em particular do sistema de gestão. Em primeiro lugar, as mudanças devem ocorrer ao nível dos gestores da educação, que reúnem as qualidades de professor, gestor e psicólogo. Essa necessidade explica os crescentes requisitos para a gestão educacional. Por um lado, um aspecto importante é a competência dos gestores educacionais, por outro lado, devemos tratar do sistema de interação entre gestores e demais participantes do ambiente educacional universitário. Somente uma combinação harmoniosa desses fatores permite que a universidade funcione no nível adequado. O problema da gestão da comunicação nas instituições de ensino é um dos mais significativos no campo do ensino superior. A comunicação é vista como um dos principais recursos para o desenvolvimento e crescimento de qualquer organização. A comunicação como processo de compartilhamento de conhecimento e informação afeta significativamente a eficiência de uma organização. O desafio da gestão da comunicação está principalmente no fato de não haver critérios claros para monitorar o ambiente de comunicação. Esse fato atualiza os problemas da pesquisa empírica da gestão da comunicação no sistema de ensino universitário. A dimensão mais importante da otimização é a melhoria do ambiente de comunicação, associada à competência dos colaboradores e ao sistema de interação. Assim, a otimização do ambiente de comunicação permite não só melhorar os processos de gestão e comunicação, mas também tem um efeito benéfico no funcionamento da universidade como um todo.

Palavras-chave: Comunicação. A eficácia das comunicações. Gestão educacional. Gestão da comunicação. A eficácia do ensino superior.

\section{RESUMEN}

La educación universitaria moderna en Rusia requiere cambios multidimensionales. Una de las direcciones principales es la optimización del entorno educativo, en particular el sistema de gestión. En primer lugar, los cambios deben producirse a nivel de los directores de educación, que combinan las cualidades de un profesor, un director y un psicólogo. Esta necesidad explica los mayores requisitos para la gestión educativa. Por un lado, un aspecto importante es la competencia de los gestores educativos, por otro lado, debemos ocuparnos del sistema de interacción entre los gestores y otros participantes del entorno educativo universitario. Solo una combinación armoniosa de estos factores permite que la universidad funcione al nivel adecuado. El problema de la gestión de la comunicación en las instituciones educativas es uno de los más importantes en el campo de la educación superior. La comunicación es vista como uno de los principales recursos para el desarrollo y crecimiento de cualquier organización. La comunicación como el proceso de compartir conocimiento e información afecta significativamente la eficiencia de una organización. El desafío de la gestión de la comunicación radica principalmente en el hecho de que no existen criterios claros para monitorear el entorno de comunicación. Este hecho actualiza los problemas de la investigación empírica de la gestión de la comunicación en el sistema educativo universitario. La dimensión más importante de la optimización es la mejora del entorno de comunicación, asociada a la competencia de los empleados y al sistema de su interacción. Así, la optimización del entorno de comunicación permite no solo mejorar los procesos de gestión y comunicación, sino que también tiene un efecto beneficioso sobre el funcionamiento de la universidad en su conjunto.

Palabras clave: Comunicación. La eficacia de las comunicaciones. Gestión educativa. Gestión de la comunicación. La efectividad de la educación superior. 


\section{INTRODUCTION}

In order to enhance the capabilities of both employees and the managers of higher education institutions (HEls), the effectiveness of interaction of all subjects of the educational environment, it is necessary to optimize the communication environment. Before proceeding to the specifics and program for optimizing the communication environment, it is necessary to pay attention to the key methodological approaches to the problem discussed. Among the considered methodological approaches are as follows (Gorev et al., 2018).

Systematic approach examines and evaluates the system of interactions of their structural components, the state and dynamics of communication processes inside and outside the system under consideration. The communication environment is considered as a dynamic system capable of changing when the constituent components change, affected by internal or external factors;

Situational approach considers and evaluates primarily the speed and effectiveness of the state and dynamics of communicative acts, based on specific situations. The communication environment is considered as a set of communicative acts of varying degrees of complexity. By changing the nature and other properties of communicative acts, it is possible to change the communication environment;

Organizational-adaptive approach considers and evaluates the direction and efficiency of the internal and external information flows in the organization. Since the communication environment is the information flow, then its optimization is possible by changing the direction and properties of this flow.

Note that each of the methodological approaches discussed above considers the communication environment as a dynamic phenomenon with a certain structure, which clearly indicates the possibility of changing it by influencing the structural components.

\section{LITERATURE REVIEW}

In our opinion, the systematic approach to improving the communication environment makes it possible to most effectively monitor its state and the dynamics of changes.

One of the most efficient methods of improving the communication environment, based on a systematic approach, is the so-called "scenario method" (Sergeeva et al., 2019). This method builds a number of scenarios of the state and dynamics of the communication environment, based on its past, current and required states. Modeling these scenarios, it is possible, firstly, to predict changes, and secondly, to build positive and negative scenarios for their dynamics, focusing on current conditions, resource availability and the external and internal factors. The scenario method provides the basis for a variable and detailed algorithm for optimizing the communication environment. Moreover, it allows us to identify the so-called "growth points", which enable the effective development of the communication environment (Dolzhich \& Dmitrichenkova, 2018).

In practice, the optimization consists in the development of an adaptive scenario based on certain criteria, for example, the overall effectiveness of communications, the effectiveness of certain types of communications, the level of parameters that determine the communication environment, etc (Pryazhnikov, 2018).

The use of a systematic approach and scenario method requires identifying the specifics of the communication environment of an educational institution, in particular, higher education institutions. The peculiarities of the communication environment of higher education institutions include:

the prevalence of internal communications over external, formal over informal;

the clear division of communication participants into groups, according to the type of internal and external communications. 
Based on this, we can conclude that in order to optimize the communication environment, it is required to work with its individual participants, both at the level of their personal characteristics and at the level of their interaction with each other. At the same time, the effectiveness of internal communications and the psychological climate in a higher education institution could serve as the criteria for the effectiveness of optimization (Wang et al., 2018; Volkova \& Panchenko, 2018; Sergeeva et al., 2018).

Theoretical analysis of the communication and communication management allowed us to develop a strategy for optimization of communication management in higher education institutions. The essence of this strategy is to identify and develop parameters that deeply affect the management of communications (competence, reflexivity and motivation of employees; stress resistance, optimization of the psychological climate and leveling of anxiety), correction of the process of management decisions, optimization of the administrative aspect of communication management. To accomplish these tasks, we should set clear priorities.

As we noted earlier, in higher education institutions the most important is the internal aspect of communication management, the management of internal communications (Utemov et al., 2018). Therefore, the development of parameters that positively affect the communication management is a prior and most significant goal. Of course, the rest of the factors should not be neglected, but they are rather auxiliary, since the administrative and methodological levels of communication management within the framework of higher education institutions, as a rule, are implemented at a high level and require minimal corrections.

\section{METHODOLOGY}

In the course of the experimental research carried out on the basis of the Department of Pedagogy, Psychology, Law, History and Philosophy of the Mytischi Branch (MB) of Bauman Moscow State Technical University in the 2019/2020 academic year, we analyzed the communication environment of the university and identified the specifics of the communication management and the state of the communication environment.

The diagnosed parameters were determined (Neverkovich et al., 2018; Sharonova et al., 2018; Sergeeva et al., 2019) as follows:

1. Competencies and qualities of the university staff: communicative competence, organizational competence, leadership competence, reflexivity, motivation.

2. The level of corporate culture: the psychological climate in the organization, the level of confidence between the participants in the communication process, the level of anxiety, stress resistance, qualitative features of corporate culture (mentoring, traditions, etc.), leading type of organization management.

3. The effectiveness of the management system in higher education institutions:

1) the ratio and efficiency of vertical and horizontal communications;

2) the ratio and efficiency of direct and indirect communications;

3) the ratio and efficiency of formal and informal communications;

4) the ratio of managed and unmanaged communications;

5) aggregate indicator of the communication management efficiency.

We identified the ranges of values (the parameters were mainly in the mean range of values), the relationship between the parameters and the effectiveness of communication management in the university, the features and structure of the interconnections. This allowed us to determine growth points that could potentially have the greatest dynamics and positive effect. Such points of growth are communicative, organizational and leadership competence, reflexivity, motivation of employees, psychological climate in the team, levels of anxiety and stress resistance of the 
participants (Vasilyeva et al., 2017). Effective communication skills will act as an integrative component of this program, affecting the communication process as a whole.

Based on the theoretical and methodological analysis of the problem under discussion, as well as the results of the experiment, we identified the basic principles of communication management optimization in higher education institutions:

1. Cognitive-emotional principle. Any development is impossible without the participation of emotional processes. We consider communication not only as an exchange of data, but also as the manifestation of a person's individuality. This principle makes it possible to realize hidden connections between various parameters, to promote their further development (Vasbieva et al., 2018).

2. The principle of hierarchical and systematic management. The development of information aspects of management is closely related to cybernetics - a science that studies the general principles of management of technical systems, living organisms and human collectives. According to the concepts of cybernetics, control is the main property of the system, therefore cybernetic systems are considered as control systems, control processes (Blinova et al., 2018). Since the communication process is, first of all, the exchange of information, the use of cybernetics in the analysis of this process is generally accepted and extremely effective.

Many methods of monitoring, analyzing effectiveness and predicting changes in the management environment are the result of applying the achievements of cybernetics.

3. The principle of monitoring and managing communications. This principle implies that the communication process can only be effectively controlled if the communication environment is properly monitored. The implementation of this principle is observed in the activities of PR organizations, the media, in the management of external and internal communications of any organization (Sokolova, 2003).

The essence of this principle lies in the identifying, ranking and classification of factors influencing the communication environment. In our study, the principle of monitoring and managing communications occupies one of the leading places and largely determines the logic of work (Sokolova, 2007).

\section{RESULTS AND DISCUSSION}

The participants in the experiment were 54 employees of the university. When organizing a psychological and pedagogical experiment, we set the following goals:

- to investigate the level of effectiveness of communication management using operational techniques (G. Rinne, diagnostics of the effectiveness of management systems; T. Miles, diagnostics of the characteristics of the communication process) as the most valid in the study of management processes and the competencies and qualities of employees of higher education institutions; experiment.

- to develop optimization methods and study the dynamics of its changes during the

To achieve the goals, a complex psychological and pedagogical experiment was carried out, consisting of the indicative and formative stage.

When analyzing the experimental results, we used methods of correlation analysis, nonlinear distribution of data and other methods of mathematical statistics (Sergeeva et al., 2017). To present the results, the method of absolute scales was used, which allows, with a slight error (no more than $2 \%$ ), to compare the data obtained in different measurement scales and having different evaluation criteria. The difference between the measurement scales and the system for evaluating the experimental results justifies using this method.

The results are clearly presented in the form of diagrams. Generalized scale of measurements from 1 to 100 , evaluation criteria: 
1-27 - low level;

27-59 - medium level;

59-77 - high level;

77-100 - very high level.

Taking into account the results and the applied mathematical methods of analysis, the secondary elements of the studied parameters were omitted and the averaged values were presented in the study. This allowed us to see the big picture. An in-depth study of particular issues was not the purpose of this study.

The results of diagnostics of the competence and qualities of employees (average values) are presented in figure 1.

Figure 1. The results of diagnostics of the competence and qualities of employees (indicative stage of the experiment).

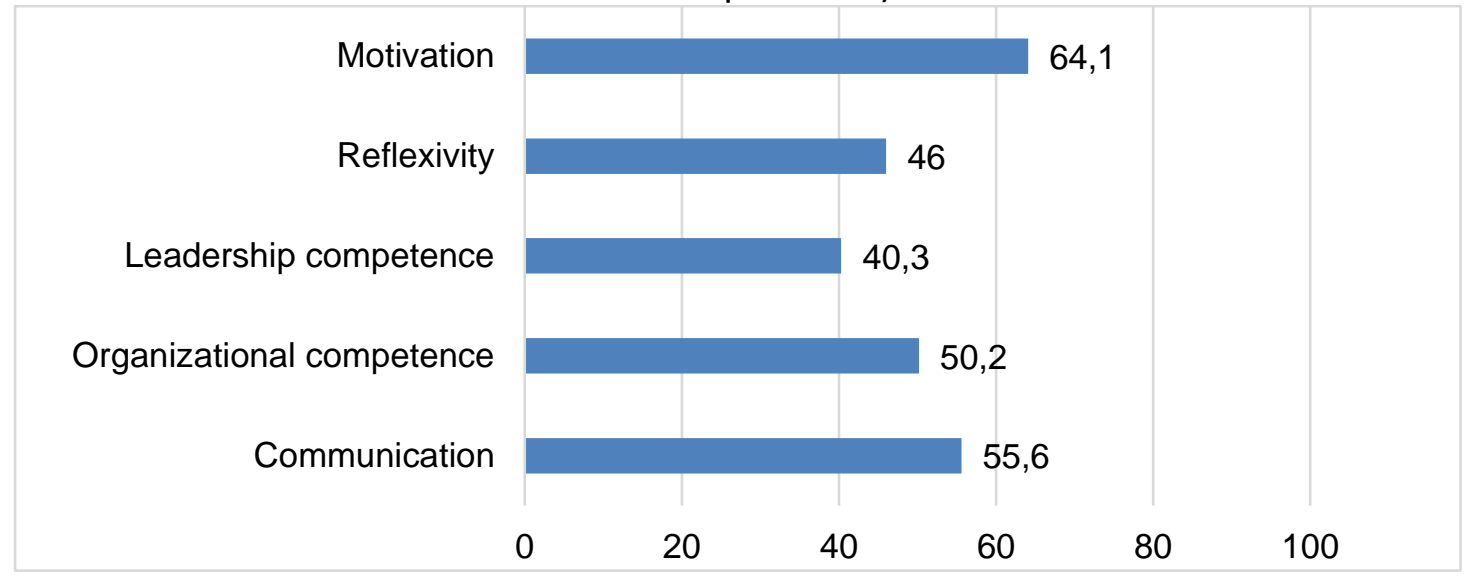

The data obtained indicate a predominantly medium level of the studied parameters. The parameter "leadership competence" is low and has a small range of deviations. According to G. Rinne (Bírová et al., 2018), such values of indicators are caused by the fact that employees have not worked out ways to show initiative, which significantly complicates the implementation of communication management. The indicator of motivation has high level, but of all parameters it demonstrates the largest range of deviations. This testifies to the difficulties of a certain proportion of the staff in achieving professional tasks (Sergeeva et al., 2018; Sokolova et al., 2018).

Reflexivity index is in the range of medium values. However, the deviation of this parameter is the smallest of all. These results indicate insufficient development of reflexive skills, which is a serious obstacle for the communication management, because it is the high level of development of reflexivity that makes this process flexible enough to respond to changes. It should also be borne in mind that feedback mechanisms directly depend on the reflexivity (Sergeeva et al., 2018).

Indicators of leadership and communicative competence are in the range of medium values, while the spectrum of deviation tends towards high values. This indicates that the organization has a significant proportion of experienced employees with a high level of professionally important qualities, but the proportion of employees whose indicators of these parameters are approaching the low threshold is also quite significant. The data obtained will be taken into account when implementing the formative stage of the experiment.

The results of diagnostics of the corporate culture level in the university (average values) are presented in figure 2 . 
Figure 2. The results of diagnostics of the corporate culture level in the university at the indicative stage of the experiment.

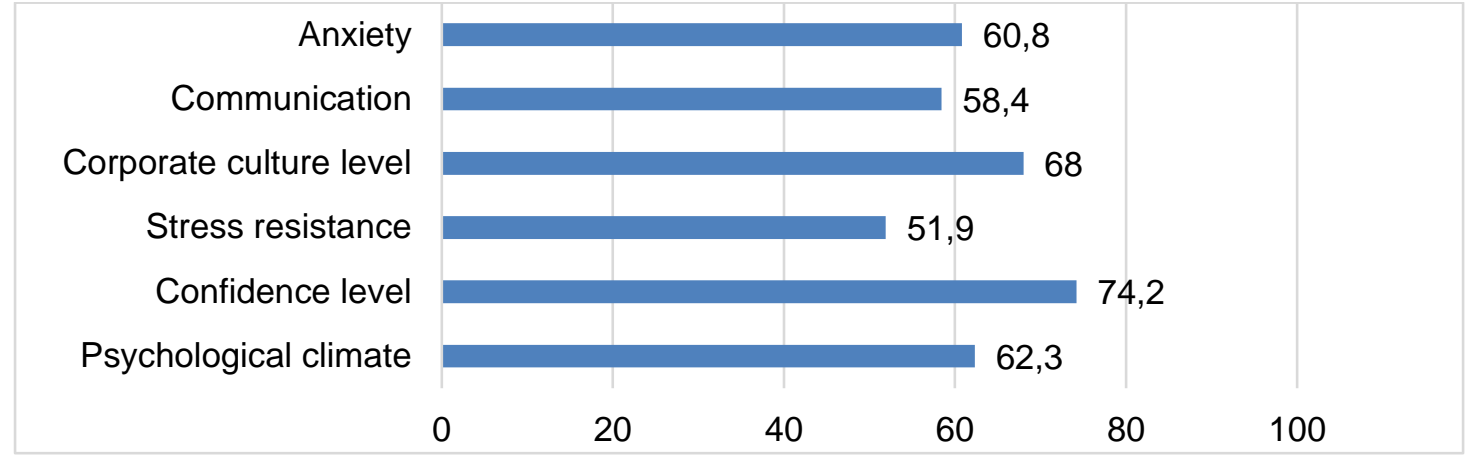

The study of the communication process made it possible to identify the parameters, which will help us to significantly optimize the effectiveness of communication management. The results of diagnostics are presented (average values) in figure 3.

Figure 3. Results of diagnostics of the communication management effectiveness at the indicative stage of the experiment.

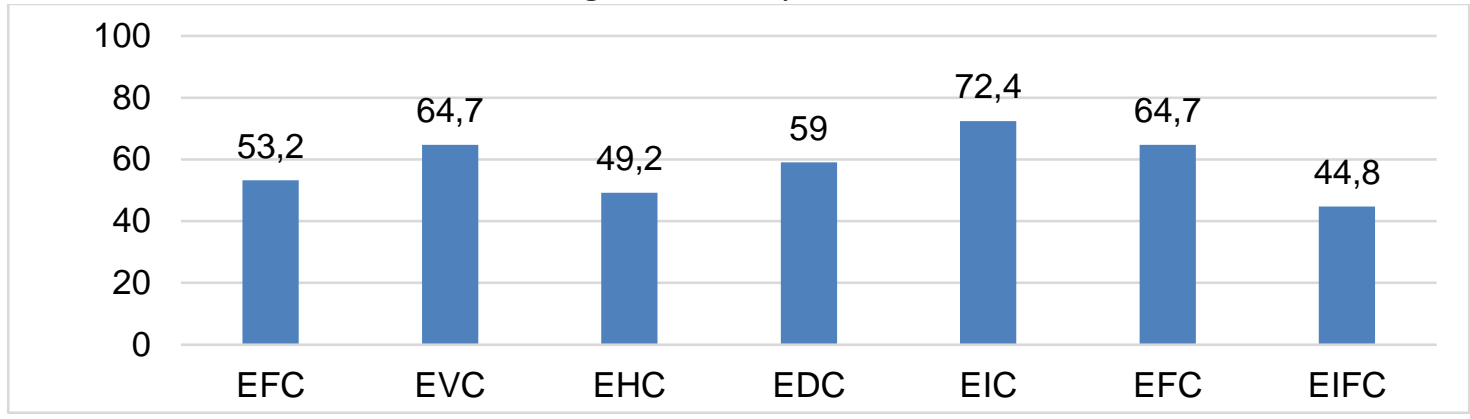

$\mathrm{EFC}$ - efficiency of communications management (integral indicator); EVC - efficiency of vertical communications; EHC - efficiency of horizontal communications; EDC - efficiency of direct communications; EIC - efficiency of indirect communications; EFC - efficiency of formal communications; EIFC - efficiency of informal communications.

The results of diagnostics of the communication management effectiveness show mainly medium and high values of the parameters. The most significant indicator of EFC has medium level of development, but closer to high and has a slight positive trend.

In order to analyze the structure of relationships and more detailed understanding of the interaction of studied parameters, a correlation analysis was carried out (Tables 1-3).

Table 1. Correlation relationships between the competences of employees and the level of corporate culture in the university.

\begin{tabular}{lllllll}
\hline Parameters & $\begin{array}{l}\text { Stress } \\
\text { resistance } \\
\text { management }\end{array}$ & Anxiety & Communication & $\begin{array}{l}\text { Corporate } \\
\text { culture level }\end{array}$ & $\begin{array}{l}\text { Psychological } \\
\text { climate }\end{array}$ & $\begin{array}{l}\text { Confidence } \\
\text { level }\end{array}$ \\
\hline $\begin{array}{l}\text { Communicative } \\
\text { competence }\end{array}$ & & -0.70 & 0.93 & 0.64 & 0.81 & \\
$\begin{array}{l}\text { Organizational } \\
\text { competence }\end{array}$ & & & 0.59 & & 0.75 & 0.78 \\
$\begin{array}{l}\text { Leadership } \\
\text { competence }\end{array}$ & & & & 0.78 & 0.84 & \\
$\begin{array}{l}\text { Reflexivity } \\
\text { Motivation }\end{array}$ & 0.83 & -0.82 & 0.87 & & & 0.65 \\
\hline
\end{tabular}


Analysis of the table data allowed us to conclude that communicative, organizational, leadership competence and qualities (reflexion, motivation) are associated with the peculiarities of corporate culture in higher education institutions, but this relationship is largely uneven. The most significant are the connections of reflexivity and motivation with the peculiarities of corporate culture. Their ramifications and strength make it possible to draw a conclusion about the importance of these parameters for corporate culture, especially with regard to stress resistance and anxiety. At the same time, the competence of employees is decisive for such parameters as the confidence level and psychological climate. The relationship between organizational competence and the confidence level $(r=0.78)$ is explained by the structure of the communication process in higher education institutions, when the confidence between employees largely depends on the organization of this process.

Analysis of the matrix presented in Table 2 proved that there is a strong relationship between the competence and qualities of employees with the effectiveness of communication management.

Table 2. Correlation relationships between the competence of employees and the effectiveness of communication management.

\begin{tabular}{llllll}
\hline Parameters & $\begin{array}{l}\text { efficiency of } \\
\text { communication } \\
\text { management } \\
\text { (integral } \\
\text { indicator), EFC }\end{array}$ & $\begin{array}{l}\text { efficiency } \\
\text { vertical } \\
\text { communica- } \\
\text { tions, EVC }\end{array}$ & $\begin{array}{l}\text { officiency of } \\
\text { horizontal } \\
\text { communications, } \\
\text { EHC }\end{array}$ & $\begin{array}{l}\text { efficiency } \\
\text { direct } \\
\text { communica- } \\
\text { tions, EDC }\end{array}$ & $\begin{array}{l}\text { officiency } \\
\text { informal } \\
\text { communica- } \\
\text { tions, ElFC }\end{array}$ \\
\hline $\begin{array}{l}\text { Communicative } \\
\text { competence }\end{array}$ & 0.87 & 0.76 & 0.88 & 0.82 & 0.75 \\
$\begin{array}{l}\text { Organizational } \\
\text { competence }\end{array}$ & 0.78 & 0.73 & & 0.84 & 0.69 \\
$\begin{array}{l}\text { Leadership } \\
\text { competence }\end{array}$ & 0.81 & 0.85 & 0.82 & & 0.86 \\
$\begin{array}{l}\text { Reflexivity } \\
\text { Motivation }\end{array}$ & 0.78 & 0.62 & 0.59 & 0.55 & 0.81 \\
\hline
\end{tabular}

The lack of connection between organizational competence and EHC (efficiency of horizontal communications) is explained by the fact that this type of communication is highly spontaneous and rarely long enough for its purposeful organization. The lack of connection between leadership competence and EDC (efficiency of direct communications) is explained by the dominance of formal acts that do not require leadership competencies.

The connections between reflexivity and motivation with the stated parameters are uniform. The relationship between reflection and EIFC (efficiency of informal communications) $(r=0.81$ ) indicates that informal communication in an organization is largely due to the development of reflexive skills. This could be related to the need for constant rethinking of information and the importance of feedback. The analysis of interconnections allowed us to conclude that the purposeful development of the indicated parameters would have a positive impact on the communication management in the university.

The analysis of the matrix presented in Table 3 confirmed a high degree of correlation between the level of corporate culture and the effectiveness of communications management. 
Table 3. Correlation relationships between the level of corporate culture and the effectiveness of communication management at the indicative stage of the experiment.

\begin{tabular}{|c|c|c|c|c|c|}
\hline Parameters & $\begin{array}{l}\text { efficiency of } \\
\text { communications } \\
\text { management } \\
\text { (integral } \\
\text { indicator), EFC }\end{array}$ & $\begin{array}{l}\text { efficiency of } \\
\text { vertical } \\
\text { communications, } \\
\text { EVC }\end{array}$ & $\begin{array}{l}\text { efficiency of } \\
\text { horizontal } \\
\text { communications, } \\
\text { EHC }\end{array}$ & $\begin{array}{l}\text { efficiency of } \\
\text { direct } \\
\text { communications, } \\
\text { EDC }\end{array}$ & $\begin{array}{l}\text { efficiency of } \\
\text { informal } \\
\text { communications } \\
\text { EIFC }\end{array}$ \\
\hline $\begin{array}{l}\text { Stress } \\
\text { resistance }\end{array}$ & 0.82 & 0.66 & 0.79 & & 0.63 \\
\hline Anxiety & -0.80 & & -0.78 & & -0.82 \\
\hline Comminication & 0.88 & 0.75 & 0.84 & 0.79 & 0.87 \\
\hline $\begin{array}{l}\text { Confidence } \\
\text { level }\end{array}$ & 0.71 & & 0.83 & & 0.74 \\
\hline $\begin{array}{l}\text { Psychological } \\
\text { climate }\end{array}$ & 0.84 & 0.76 & 0.90 & 0.63 & 0.92 \\
\hline $\begin{array}{l}\text { Corporate } \\
\text { culture level }\end{array}$ & 0.73 & 0.70 & & 0.69 & \\
\hline
\end{tabular}

\section{CONCLUSION}

The results of the research work confirmed that the implementation of the communication management optimization program in higher education institutions had positive impact on the efficiency of communication management in the institution:

1) parameters of the competence and qualities of employees increased by $12 \%$ in comparison with the indicative stage of the experiment;

2) level of anxiety among the subjects decreased and reached a medium value, the stress resistance indicator increased and reached a high value. There have been significant positive changes in the parameter "psychological climate";

3) analysis of the interrelations of the studied parameters at the control stage of the experiment testifies to the essential improvement;

4) there is a progressive dynamic of the effectiveness of communication management in the aggregate at more than $15 \%$ of the control stage of the experiment.

In the course of the research, the main parameters affecting communication management were identified: communicative, organizational, leadership competence, motivation for selfrealization in the profession, reflexive skills of employees, as well as the level of corporate culture in the organization. The mathematical analysis of the experimental results confirmed the importance of these factors.

The results of diagnostics of communicative, organizational, leadership competence, motivation for self-realization in the profession, reflexivity, the level of corporate culture revealed mainly medium development. At the final stage, we observed a positive dynamic of all the studied parameters.

The combination of communicative, organizational, and leadership competence of employees is a key factor improving the management of communications.

\section{REFERENCES}

Araujo, A., \& Silva, I. P. (2020). Maker culture and educational robotics in physics teaching: developing an automated traffic light in high school. Journal of Research and Knowledge Spreading, 1(1), e11654.

Bírová, J., Kružlík, P., Kalimullin, A., Sokolova, N., Haroun, Z., Králik, R., Vasbieva, D. (2018). Mathematical and Statistical Bibliometric Indicators for Scholars in the Field of Romance Languages and Linguistics. EURASIA: Journal of Mathematics, Science and Technology Education, 14(12). 
Blinova, S., Dugina, T., Zabolotskikh, A. (2018). Teaching mixed nationality groups (on the example of students from the Northern Caucasus region). INTED 2018: Proceedings of the 12th International Technology, Education and Development Conference (pp. 7977-7982) Valencia, Spain.

Dolzhich, E., Dmitrichenkova, S. (2018). Computer science terminology (a case study of the Spanish language). INTED2018: Proceedings of the 12th International Technology, Education and Development Conference (pp. 25562559) Valencia, Spain.

Gorev, P., Telegina, N., Karavanova, L., Feshina, S. Puzzles as a didactic tool for development of mathematical abilities of junior schoolchildren in basic and additional mathematical education. EURASIA: Journal of Mathematics, Science and Technology Education Vol: 14 num 10 (2018): 178-185.

Neverkovich, S., Bubnova, I., Kosarenko, N., Sakhieva, R., Sizova, Zh., Zakharova, V., Sergeeva, M. (2018). Students' internet addiction: study and prevention. Eurasia Journal of Mathematics, Science and Technology Education, 14(4), 1483-1495.

Oliveira, A. M., Gerevini, A. M., \& Strohschoen, A. A. G. (2017). Diário de bordo: uma ferramenta metodológica para o desenvolvimento da alfabetização científica. Revista Tempos e Espaços em Educação, 10(22), 119-132.

Pryazhnikov, N.S., Rumyantseva, L.S., Sokolova, N.L., Bakhtigulova, L.B. (2018). Career guidance: harmonization of points of view. Scientific dialogue, 3, 289-303.

Rodrigues, B. M., Santos, J. E. B., \& Vasconcelos, C. A. (2020). Conceptions of undergraduate students in Chemistry on the use of interactive interfaces in and for the activities developed in the distance course. Journal of Research and Knowledge Spreading, 1(1), e11649.

Santos, J. E. B. (2020). Cartographic narratives: the teaching of mathematics and ICT. Journal of Research and Knowledge Spreading, 1(1), e11645.

Sergeeva, M., Bondarenko, N., Shebzuhova, T, Vartumyan, A., Lesnikova, S. (2018). Scientific substantiation of the conception of continuous economic education development. Turkish online journal of design art and communication (TOJDAC), 8, 178-185.

Sergeeva, M., Shumeyko, A., Serebrennikova, A., Denisov, A., Bondarenko, N., Getmanova, E. (2018). Innovative pedagogical experience in practice of modern education modernization. Modern Journal of Language Teaching Methods, 8(11), 814-823.

Sergeeva, M.G., Bondarenko, N.G., Shebzuhova, T.A., Solovyov, B.A., Parinov, D.V., Shvedov, L.A., Ovchinnikov, A.P. (2019). Verification of management-support of professional and educational trajectory of students in the sociocultural educational environment of the university. Amazonia Investiga, 8(18), 5-14.

Sergeeva, M.G., Flyagina, V.Yu., Taranenko, I.V., Krasnova, E.V., Vilkova, A.V. (2017). The interaction of labour market and educational services market considering social partnership mechanism and specificity of regional educational policy. Ponte, 73(12), 2.

Sergeeva, M.G., Gubarkov, S.V., Zhigalov, K.Yu., Kurmaeva, I.I., Tolmachev, A.V. (2018). Quality management of services of the higher education. Ponte, 74(1), 34-47.

Sergeeva, M.G., Stepanyan, T.M., Spector, A.A., Komov, M.S., Latysheva, N.A., Okhotnikov, I.V., Shvedov, L.A. (2019). Formation of economic competence of the head of the educational organization in terms of professional development. Revista San Gregorio, 30, 1-8.

Sharonova, S., Trubnikova, N., Sokolova, N. (2018). Interpreting religious symbols as basic component of social value formation. European Journal of Science and Theology, 14(3), 117-129.

Sokolova, N.L. (2003). On the components of the meaning of the units of speech etiquette. Philological sciences, 5, 95.

Sokolova, N.L. (2007). Thematic group “Acquaintance” in the English-speaking culture of communication. Bulletin of the Moscow State Linguistic University, 532, 218-227.

Sokolova, N.L. (2018). Professional evolution of a school teacher based on advanced pedagogical experience. Scientific dialogue num 9 (2018): 376-381.

Utemov, V., Khusainova, R., Sergeeva, M., Shestak, V. (2018). Full Packaged Learning Solutions for Studying Mathematics at School. Eurasia Journal of Mathematics, Science and Technology Education, 14(12).

Vasbieva, D.G., Sokolova, N.L., Masalimova, A.R., Shinkaruk, V.M., Kiva-Khamzina, Y.L. (2018). Exploring the EFL teacher's role in a smart learning environment - a review study. XLinguae, 11(2), 265-274. 
Vasilyeva, I.I., Sokolova, N.L., Mikheeva, N.F. (2017). Some trends in the use of ICT in Russian scientific research in the field of teaching foreign languages and translation in universities (2012-2017). Problems of Applied Linguistics, 27, 718.

Volkova, Y., Panchenko, N. (2018). Discourse variation of the concepts of destructive emotions. Vestnik Rossiiskogo Universiteta Druzhby Narodov. Russian journal of linguistics, 22(1), 175-194.

Wang, S., Gorbunova, N., Masalimova, A., Bírová, J., Sergeeva, M. (2018). Formation of academic mobility of future foreign language teachers by means of media education technologies. Eurasia Journal of Mathematics, Science and Technology Education, 14(3), 959-976.

Received: 4 January 2021 | Accepted: 5 February 2021 | Published: 16 February 2021

This is an Open Access article distributed under the terms of the Creative Commons Attribution License, which permits unrestricted use, distribution, and reproduction in any medium, provided the original work is properly cited. 